\title{
The Implementation of Online Teaching during Pandemic and Its Problems in EFL Classrooms
}

\author{
Dian Yurnita Sari ${ }^{1 *}$ and Yetti Zainil ${ }^{2}$
}

\author{
${ }^{12}$ English Department, FBS Universitas Negeri Padang, Padang, Sumatra Barat, 25153, Indonesia \\ *Corresponding author. Email: dianyurnitabeni82@gmail.com
}

\begin{abstract}
Due to the Pandemic situation, online teaching is recommended by the Indonesian government. However, the implementation of online teaching may still become a dilemma for English teachers since each school has different facilities, students' and teachers' competence, and schools' different conditions. This paper presents the findings of a study of the implementation of online teaching English that focus on the teaching and learning process: pre-teaching, whilst teaching and post-teaching activity and its problem in one of the senior high schools in Padang. Descriptive qualitative is used in this research. The data is collected through the recording of classroom observation of English teachers in the EFL classroom and the Stimulated Recall Interview (SRI) with the respective teachers. The Stimulated Recall Interview was done to find out teachers' problems in online teaching. The participants are five English teachers in SMAN 16 Padang. The result was not all English teachers did all the activities in each stage suggested. In preteaching activity, the teachers take attendance, greet and give motivation to the students. Then, they jump to give the assessment to the students and ask them to submit it. Some of the activities in whilst and post-teaching activity were mot done by the teachers. These were because they have the problem in pre-teaching activity: the preparation, choosing, and using the appropriate platform and strategy based on learning objective. Thus, the effect of these situations was that the online teaching of English became not effective.
\end{abstract}

\section{Keywords: Online teaching English, Pandemic Covid-19, EFL Classrooms}

\section{INTRODUCTION}

Online learning is one of the teaching and learning methods that teachers and students use in the development of new era or industry revolution. Teaching and learning method in this new era focus on teachers and students are able to use knowledge and technology in the teaching and learning process. Barbara [1] mentions that online learning is one of the fastest growing trends in teaching and learning process that uses technology. Similarly, Verawardina \& Jama [2] states that the implementation of online learning is the evidence of industrial revolution 4.0 where the access of technology is unlimited. It can be concluded that online learning is one of the ways that teachers and students use in education process whereas they should be able to use the technology; it can be used for online or distance learning.

Today, due to the Pandemic situation, Indonesian government recommended online learning. Teachers and students are asked to teach and learn at home. The government rule, number 3-year 2020 about the covid 19 in education unit mentions that teaching process should be done at home (work for home) and learning is at home as well (learning for home).
Varron [3] said that the teacher is considered as the main part or the main role in the teaching and learning process. It means that the teachers are the main part in education without teachers the process of teaching and learning cannot run well. Also, he said that the teacher is a mover or the key in the successful of teaching and learning process. Therefore, the successful of online teaching is also based on the teachers' skill and competencies.

Fatimah [4] pointed out that online teachers should consider online teaching skill and competencies for helping in designing professional develop programs. Furthermore, teachers' competencies in online teaching gives the effect to the students' achievement. Similarly, Paula, Lawrence, Shannon, Janet and Brian [5] stated that online teachers should have a broader set of skills and competencies in getting the students' success. It can be concluded that teachers should have the skills and competencies in online teaching in order to design good teaching and learning program and to ensure the students success.

Online and offline teaching involve making lesson plan, preparing the media and learning sources, preparing assessment and evaluation. In lesson plan, it includes pre teaching activity, whilst teaching activity, 
and post teaching activity. The pre teaching activity is the beginning of teaching and learning process. It establishes the preparation of materials that will be thought, media that will be used, preparation of the students and class in focusing the teaching and learning process and giving the motivation in learning.

Whilst activity is the main teaching and learning process in achieving the learning objective whereas the teachers understand about the material, the using of learning strategy, media, and the teachers' competence to encourage the students join and participate in learning process. Post activity is the activity that is done to end the teaching and learning process. It covers the assessment of the students and reflection to evaluate what the students have been learned.

Learning evaluation is needed to evaluate the readiness of students' preparation in learning, process, and the outcome of learning. Evaluation is used for teachers to plan the remedial and enrichment. It is used to improve the teaching and learning process.

Since online teaching and learning English is the first experience implemented by all schools in Indonesia whereas each school has the different facilities, different students' and teachers' competence and different condition, it arises different problems. SMAN 16 Padang is one of the schools that also uses online learning. This school is located in the suburb of Padang with the difficult internet access but this school has the big motivation to do the online teaching and learning process. Also, this school has the motivation and supporting from headmaster and teachers in doing the changing for the better education although the changing have the challenge. This is the main reason for choosing this school to do the research.

Based on the sharing information with one of the English teachers in SMAN 16 Padang said that online teaching is quite hard for them because this is the first experience for them to adapt to the current situation. As a result, they have some problems in implementing it.

It can be seen from the result of evaluation in the first semester, year 2020/2021, a half of the students get the low mark in semester examination. It shows that the students do not understand what have been taught to them. Based on Putri, Purwanto, Pramono, Asbari, Wijayanti and Chi Hyun [6] finding, they state that the teachers cannot cover the learning outcomes fast like in offline class.

Furthermore, Bao [7] says online learning causes the students become lack of learning disciplines at home. There is no their responsibility for studying at home. Also, Nambiar [8] did the study and found that some of the students feel bored and stress with the pressure of the lot of assignment that should be completed on time. They feel that there is no teaching and learning process. Not only students but also teachers feel bored teaching at home. Putri, Purwanto, pramono, Asbari, Wijayanti and Chi Hyun said that teachers are bored being at home. They have to rework in making the new lesson plan. Also, Carnevale (2004); Hampel and Hauck [9] found that there is a less motivation of students in online English teaching and learning process. Next, Paulina [10] did the study on the challenge and opportunities in the implementation of online teaching English. She found that the lack of direct interaction with learners and the sudden change of setting were strongly affected the participant's own learning process.

Based on the explanation above, the purpose of this research is to figure out the real implementation of online teaching English and the problems in each stage of teaching and learning process that focus on pre teaching activity, whilst teaching activity, and post teaching activity. Hopefully, it gives the consideration for the school, government, other school to find the solution of the problems. Also, it gives consideration for the government to be ready fast in using online learning or consideration to decline using online teaching and learning in Senior High School. Also, through implementation and its problem of online teaching give a reference to next researchers to do the research.

In order to achieve the goals of this study, the following research questions were addressed to conduct (1) How do the implementation of online teaching in teaching and learning process: pre teaching activity, whilst teaching and post teaching activity in EFL classroom during Covid-19 pandemic? (2) What are the problems in implementing the online teaching in the teaching and learning process: pre teaching activity, whilst teaching activity and post teaching activity at SMAN 16 Padang during the Covid-19 pandemic?

\section{METHODS}

This research will use the qualitative research. According to Monique Hennink, Inge Hutter, and Anjay Bailey [11], qualitative research is the method which permit the researcher to conduct the people's experience specifically through a particular research method likedept interview, observation, focus group discussion, content analysis and life histories. Also, they stated that qualitative research examines people in their natural settings, identifying how their experiences and behavior are focused on the context of their lives, like the social, cultural or physical context which they stay on.

It can be concluded that qualitative research is an approach to conduct the people experience and their behaviors in their natural settings or their lives by using a specific research method such as interview and observation.

\subsection{The participants}

The participants were five English teachers of SMAN 16 Padang, West Sumatra, Indonesia. They referred to as Teacher A, Teacher B, Teacher C, Teacher D, and Teacher E. They were recorded when they taught English whereas one session was 60 minute in a week for English compulsory, and 90 minute in a week for English specialization. 
This research will involve the English teachers in SMAN 16 Padang. It is located at Jl. Bukit napa, Kuranji, Padang. This school has 66 teachers. There are five English teachers there. All of the English teachers there will be the participants of this study. They graduated from different university. Two were from Universitas Negeri Padang. Three teachers were from Bung Hatta University. All of them are women and have gotten the certification license "Sertifikasi Guru".

\subsection{Data collection.}

The data were collected from July to march 2020 on the first semester of 2020/2021. In describing the implementation of online teaching in EFL class, the researcher recorded while observing and monitoring the English teachers' activities in online teaching process It was done at teachers' office of SMAN 16 Padang because the teachers were asked to come to school for teaching based on their schedule with the Covid protocol, and the students were at home for studying. Then, researcher filled the observation checklist that related to the indicator of each stage: pre-teaching, whilst teaching, and post teaching activity.

In getting the problem of implementation of online teaching in EFL classroom, the researcher used Stimulated Recall Interview. This is because this research did the observation teachers in the classroom, it was very useful to use Stimulated Recall Interview. According to Zainil [12] Stimulated Recall Interview gave the knowledge about the teaching and learning process and helped the teachers to understand and analyse their own practice in the classroom that would be difficult to understand. It means that SRI makes the teachers become understand and have the ability to analyse how they teach in the classroom. In another word, it gives the reflection of their teaching practice in the classroom.

The Stimulated Recall Interview had done toward the five English teachers by open ended questionnaire. Open ended questions gave detail information from the participation, such as, attitudes, feelings, and their understanding about the topic. The participants had the chance to explain whether they did not understand about the questions or they did not have opinions about the topic. Stimulated Recall Interview used to get the data about the English teachers' deep information about the online teaching English implementation and the problems that teachers had in applying online teaching English during the covid 19 pandemic.

After asking the date and times of five English teachers when they could do the interviewing one by one in the different time, the teachers asked open-ended questions related to the teachers' implementation and their problems on online teaching and learning English process in each stage of teaching activity; pre teaching activity, whilst teaching activity, and post teaching activity. The English teacher would be interviewed by Bahasa Indonesia to make easy to understand the interviewing process. The researcher and teacher watched the recording of English teachers in the online teaching and learning process. The recording could be stopped when the researcher had the questions and the teacher gave the comments. The interview also recorded and noted in order to be interpreted easily.

\subsection{Data Analysis}

Observation checklist was used for analyzing the data of how the implementation of online teaching in EFL class. The researcher got and found how the English teachers applied online teaching in online classroom whether the English teachers do all the indicator in figure 1 or not do. Then, the summarizing of how the English teachers applied online teaching and learning process in each stage had been gotten.

Stimulated Recall Interview transcript was used to find the problems in implementation in online teaching and learning English process. The researcher identified all the answers from the teachers about the problem of online teaching and learning English process in each stage. Then, the information that related to the problem online teaching and learning process was taken and the un related information to the topic was reduced. Lastly, the summarizing of the teachers' answer or explanation was written in the form of essay.

\section{RESULTS AND DISCUSSIONS}

The result of the implementation of online teaching in EFL classroom can be seen in Appendix 1. It can be seen in figure 1 that teachers applied online teaching in different ways in each stage.

\subsection{In the stage of pre teaching activity.}

Teacher A and Teacher B had done all the indicators in each stage of online teaching and learning process in EFL classroom. In pre teaching activity, they prepared and thought the media, material, strategy based on the learning objective of each skill of English subject. Google classroom was the media that school suggested to use because it was easy for teachers and students. Besides, they used Whats App and google meeting. They used the material that they got from many sources, such as revision book curriculum 13, LKS ( students' exercises), any English learning from YouTube. They chose the material based on the characteristic of students.

The teachers B,C, and D were the same in pre teaching activities. They prepared the platform for online teaching. They usually used Whats App and sometimes they used google classroom. They chose whats App because it is easy to use and free message application. This is because they have the problem in IT ( technology), so that whats app was the media for them. In preparing the material, they used only the book of revision curriculum 13 because each of students have it. the strategy that they used were they gave the instruction to read the revision book curriculum 13 and did the task.

They had the problem in using the appropriate strategy for online teaching process because they still 
had lack information of online teaching strategy. As the result, they used discussion strategy whereas the teacher and students just discussed what the students did not understand about the material. Checking the attendance, greeting, chatting to motivate the students were the usual activities that they had done in online class through google classroom.

\subsection{In the stage of whilst teaching activity.}

In whilst teaching activities, the teacher $\mathrm{A}$ and E shared the material through the google classroom based on learning hierarchy through you tube that was sent through google classroom, google meeting or whats App. They could encourage the students to join and active in online class, particularly the science class. However, not all the students joined the online class. When they taught in social class, they had the problem to motivate the students to join the class. Only half the students were in online class.

In evaluation process, sometimes, they did the pre test for learning reading and writing. They did after sharing the material one day before learning. The students were asked to learn before online teaching and learning process. Then, they gave some questions about the topic given through google classroom or google form. The teacher A and teacher E always gave the task through google classroom based on the learning objective and students competence and gave the feedback and evaluate the students' task quickly. This is to motivate the students to do the task every meeting. Moreover, this is to evaluate the students how far the students understand about the material. These two teachers had good competence in teaching because they had, clear, correct and easy spoken and written. Otherwise they had the problem in evaluating the students because the task were given through google classroom which the task were the same among them. Nambiar points out it is hard to assess the students and to know if they understand or no. It shows that during online class, the teachers assess the students based on the task given to them, not based on the students' understanding of the lesson. Sometimes, the tasks that they submit are the same with their friends. For example, the teachers ask to create the dialogue of sympathy expression with different situation, their submissions are the same in fact they are in different place.

Teacher B, C and D in whilst teaching activity, asked the students to do the task after they gave the instruction to read and learn the material. It caused the teachers could not encourage the students to join and active in online teaching and learning process. The students just took the absent and then they were not in class. Teacher B said "we have asked them to take the absent on time but only half the students took the absent. This is much happen in social class. When we teach in science class, there is only five students did not take the absent.

The big problem is the task of students. Teacher C said "most of the students were late to submit the task. I give them the time submission was about one day but they sent more than one day even more some of them did not submit. How do we evaluate them".the students' character on learning become less effective. Most of them are lack of self-discipline in learning at home. They cannot manage their selves and their times to study at home whether they should do the task or exercises on time

In giving the task, the teacher $\mathrm{B}, \mathrm{C}$, and $\mathrm{D}$ gave the task more than ten questions. They tended to teach reading and writing skill, listening and speaking were ignored by the teachers. They said that they could not teach speaking, listening and grammar because we could not use the application like video conference for teaching.

When seeing the way of teachers share the material and task they give is hard for students to understand because the students have different competence and characteristic. Every meeting the teacher B,C,and D always do the same strategy in online teaching. This is make the students bored and about the task makes the students stress because they do not understand about the material given. They need the explanation from teachers but the teachers can not use the application to meet them in different place.

\subsection{In the stage of post teaching activity.}

In post teaching activities, the teacher $\mathrm{A}$ and $\mathrm{E}$ made the conclusion of teaching and learning process when they were in google meeting but when they were not in video conference, they ignored that. They did not do remedial and enrichment because the limitation of time. It is different with teacher B,C and D, they did not do the indicator in post teaching activity.

\section{CONCLUSIONS}

It can be concluded that in pre teaching activities, the teachers have prepared the material and platform for teaching but some teachers prepare the material and platform that do not relate with the learning objective of each skill of English. this is because the IT problem. Most of them have problem in using the appropriate strategy in teaching online. It will give the effect to the whilst teaching activity, that most of the teachers are not optimal in giving the material and using the various platform based on the learning objective. Also they are not optimal in giving the assignment that relate with the students' competence and the situation. In post teaching activity, the teachers do not do the indicator. This is because they have the problem in time. Teaching and learning process during covid is limited by the government.

\section{AUTHORS' CONTRIBUTIONS}

Implementation of online teaching in EFL class is hoped as an evaluation for the future teaching in order to improve the online teaching process. Particularly, for the Senior teachers who are as the main role play in better teaching and learning process. 


\section{ACKNOWLEDGMENTS}

I would like to thank to Allah for giving me full strength to complete this paper. A lot of thanks to my advisor, Dra. Yetti Zainil, M.A. Ph.D for all her valuable advice and guidance. Special thanks to my husband, kids and my family for giving me a support. This paper is far from perfect that needs critics and suggestion. I expect this study can be useful for teachers and other researcher.

\section{REFERENCES}

[1] Barbara Means, YT. Evaluation of Evidence-Based Practices in Online Learning: A Meta-Analysis and Review of Online Learning Studies U.S. Department of Educatio. Washington, D.C., 2009.

[2] Verawardina, U., \& Jama, J. Philosophy TVET di era derupsi revolusi industri 4.0 di Indonesia. Jurnal Filsafat Indonesia, vol.1 (3), 2018, pp. 104 111.

[3] Varon. The Elements of the Teaching and Learning process. Varon Experts Column.com., 2016.

[4] Fatimah, A. Albrahim, Ph.D. Online Teaching Skill and Competencies. The Turkish Online Journal of Educational Technology-januari, vol. 19, 2020.

[5] Paula, Lawrence, Shannon, Janet and Brian. The identification of competencies for online teaching success. The Pennyslvania State University, 2012.

[6] Putri, Ratna Setyowati et al. "Impact of the Covid19 pandemic on online home learning:An explorative study of primary schools in Indonesia." International journal of advance science and technology 29 (2020): 4809-4818.

[7] Bao W. COVID-19 and online teaching in higher education: A case study of Peking University. Hum Behav Emerg Technol. 2020 Apr;2(2):113-115. doi: 10.1002/hbe2.191. Epub 2020 Apr 7. PMID: 32510042 ; PMCID: PMC7262082.

[8] Nambiar, D. (2020). The impact of online learning during COVID-19: Students' and teachers' perspective. The international journal of Indian psychology,8(2),783793. https://doi.org/10.25215/ 0802.094

[9] Carnevale, D. (2004) 'Educational technology fails to deliver on its promises, report says', The Chronicle of Higher Education, [online] Available at:http://chronicle.com/prm/daily/2004/ 06/2004062401n.htm

Hampel, R. \& Hauck, M. (2004) 'Towards an effective use of audio conferencing in distance language courses', Language Learning \& Technology, vol. 8, no. 1, pp. 6682.

[10] Paulina, Sepulveda - Escobar \& Astrid Morrison. Faculty of Education, Universidad Autonoma de Chile, Chile. Online teaching placement during the Covid -19 in Pandemic in Chile: Challenges and Opportunities.

[11] Hennink, Monique., Hutter, Inge., and Bailey, Ajay. Qualitative Research method. SAGE Publication, 2020.

[12] Zainil, Yetti. Stimulated Recall: Unpacking Pedagogical Practices of Code- Switching in Indonesia. Deakin University, 2017.

Appendix 1.

Implementation of online teaching in each stage in EFL classroom.

\begin{tabular}{|c|c|c|c|c|c|c|c|}
\hline \multirow[t]{2}{*}{ No } & \multirow{2}{*}{$\begin{array}{l}\text { Teaching } \\
\text { and } \\
\text { learning } \\
\text { process }\end{array}$} & & \multicolumn{5}{|c|}{ Teacher } \\
\hline & & & $\mathrm{A}$ & $\mathrm{B}$ & $\mathrm{C}$ & $\mathrm{D}$ & $\mathrm{E}$ \\
\hline \multirow[t]{4}{*}{1} & \multirow{4}{*}{$\begin{array}{l}\text { Pre } \\
\text { teaching } \\
\text { activities }\end{array}$} & - preparing the media/platform & $\sqrt{ }$ & $\sqrt{ }$ & $\sqrt{ }$ & $\sqrt{ }$ & $\sqrt{ }$ \\
\hline & & $\begin{array}{l}\text { - preparing the material based on the learning objective of each skill of } \\
\text { English subject }\end{array}$ & $\sqrt{ }$ & & & & $\sqrt{ }$ \\
\hline & & $\begin{array}{l}\text { - preparing and using the appropriate strategy based on the learning } \\
\text { objective }\end{array}$ & $\sqrt{ }$ & & & & $\sqrt{ }$ \\
\hline & & - check the attendance, greet, chat to motivate the students & $\sqrt{ }$ & $\sqrt{ }$ & $\sqrt{ }$ & $\sqrt{ }$ & $\sqrt{ }$ \\
\hline \multirow[t]{6}{*}{2} & $\begin{array}{l}\text { Whilst } \\
\text { teaching } \\
\text { activities }\end{array}$ & & & & & & \\
\hline & \multirow{4}{*}{$\begin{array}{l}\text { Sharing the } \\
\text { material } \\
\text { process }\end{array}$} & - sharing/giving the material based on learning hierarchy & $\sqrt{ }$ & & & & $\sqrt{ }$ \\
\hline & & - Being able to use various many platform in sharing the material. & $\sqrt{ }$ & & & & $\sqrt{ }$ \\
\hline & & - using the platform based on the students' competence and background & $\sqrt{ }$ & $\sqrt{ }$ & $\sqrt{ }$ & $\sqrt{ }$ & $v$ \\
\hline & & $\begin{array}{l}\text { - choosing the material based on the students' competence and } \\
\text { background }\end{array}$ & $\sqrt{ }$ & & & & $\sqrt{ }$ \\
\hline & Encouragin & - being able to encourage the students to join the online class & $\sqrt{ }$ & & & & $\sqrt{ }$ \\
\hline
\end{tabular}




\begin{tabular}{|c|c|c|c|c|c|c|c|}
\hline \multirow{2}{*}{\multicolumn{2}{|c|}{\begin{tabular}{|l|l|}
$\mathrm{g}$ & the \\
students in \\
online \\
classroom.
\end{tabular}}} & - being able to encourage the students active in online learning & $\sqrt{ }$ & & & & \\
\hline & & - being able to create conducive relationship between teacher and students & $\sqrt{ }$ & & & & \\
\hline & \multirow{4}{*}{$\begin{array}{l}\text { Evaluation } \\
\text { process }\end{array}$} & - doing the pre test & $\sqrt{ }$ & & & & $\sqrt{ }$ \\
\hline & & - giving the task based on the learning objective & $\sqrt{1}$ & $\sqrt{ }$ & $\sqrt{ }$ & $\sqrt{ }$ & $\sqrt{ }$ \\
\hline & & - giving the task based on the students' competence & $\sqrt{ }$ & & & & $\sqrt{ }$ \\
\hline & & - giving the feedback & $\sqrt{ }$ & $\sqrt{ }$ & $\sqrt{ }$ & $\sqrt{ }$ & $\sqrt{ }$ \\
\hline & $\begin{array}{l}\text { Language } \\
\text { competence }\end{array}$ & $\begin{array}{l}\text { - using correct, clear, and easy spoken and written language in their } \\
\text { platform used. }\end{array}$ & $\sqrt{ }$ & $\sqrt{1}$ & & & $\sqrt{ }$ \\
\hline \multirow[t]{2}{*}{3} & \multirow{2}{*}{$\begin{array}{l}\text { Post } \\
\text { teaching } \\
\text { activities }\end{array}$} & - making conclusion of teaching and learning process & $\sqrt{ }$ & & & & $\sqrt{ }$ \\
\hline & & - doing remedial / enrichment & & & & & \\
\hline
\end{tabular}

